\title{
A INSERÇÃO DAS AUDIÊNCIAS PÚBLICAS: REFORÇO OU ENFRAQUECIMENTO DA LEGITIMIDADE DEMOCRÁTICA DAS DECISÕES DO SUPREMO TRIBUNAL FEDERAL?
}

\author{
KARINA AlMEIDA GUIMARÃES PINHÃO
}

RESUMO: O presente trabalho tem por objetivo refletir sobre as audiências públicas adotadas junto aos processo de controle de constitucionalidade concentrado no Supremo Tribunal Federal e seus limites sobre os debates que cerceiam a legitimação democrática no controle de constitucionalidade. Para tanto, em um primeiro momento, se apresentará um breve contexto teórico acerca da inserção das audiências públicas, de acordo com a sua previsão legislativa e discussões ocorridas no Supremo Tribunal Federal. Em seguida, se contraporá as teses defendidas para implementação das audiências com as teses democráticas, especialmente sob a perspectiva do aumento da participação democrática no Supremo Tribunal Federal nas ações constitucionais em sede de controle de constitucionalidade concentrado. E, ao fim , se analisará criticamente as finalidade da audiência pública na perspectiva democrática indicando-se, assim, os limites da capacidade institucional deste instrumento. O presente estudo foi realizado de forma empírica e se baseia nas discussões acerca da formação da vontade política presentes no conceito de democracia, e na leitura das ações constitucionais em que se realizaram as audiências públicas no STF até 2016.

PAlavRAS-ChaVe: Legitimidade Democrática; Audiências Públicas; Controle de Constitucionalidade.

\footnotetext{
${ }^{+}$Mestre pela Faculdade de Direito da Universidade de Coimbra no Mestrado Científico em Ciências Jurídico-Políticas com Menção em Direito Constitucional. Pós-graduada em Direito Civil-Constitucional pela Universidade do Estado do Rio de Janeiro (UERJ). Graduada em Direito pela Pontifícia Universidade Católica do Rio de Janeiro (PUCRio). Pesquisadora do Laboratório Americano de Estudos Constitucionais Comparados - LAECC/PPGD-UFU. Advogada.
} 
ABSTRACT: This paper aims to reflect on the open court adopted in the judicial review process concentrated in the Brazilian Supreme Court and its limits on the debates that confront the democratic legitimacy in the control of constitutionality. To do so, the reader is initially presented to the doctrinal context about the insertion of open court in accordance with its legislative forecast and discussions in the Brazilian Supreme Court. Then, will be opposed the theses that defended the implementation of the open court with the democratic theses, especially from the perspective of increasing the democratic participation in the Brazilian Supreme Court in the constitutional actions in the control of concentrated constitutionality. Finally, the purpose of the open court in a democratic perspective will be analyzed critically, thus indicating the limits of the institutional capacity of this instrument inserted in these actions. Lastly, it should be noted that the study was conducted empirically and is based on discussions about the formation of political will in the concept of democracy and the reading of constitutional actions in which public hearings were held.

KEYWORDS: Democratic Legitimacy; Open Court; Judicial Review. 


\section{INTRODUÇÃO}

O controle judicial, abstrato e concentrado de constitucionalidade sempre se desenvolveu em torno de diversos debates que se encerram em uma visão conflituosa ou complementar, entre o Constitucionalismo e a Democracia. Nesse sentido, nesses debates, sempre se segue uma constante demanda por observância à democraticidade das instituições e, consequentemente, sobre a representação e formação da vontade popular. É importante destacar que, apesar da representação da vontade popular não é ignorada no espaço do Poder Judiciário e, pelo contrário, tem nesta o próprio limite de sua atuação. Contudo, diferentemente dos demais poderes estatais (Legislativo e Executivo) e, especialmente o Supremos Tribunal Federal (STF), cumpre representar a vontade popular que também se encontra inscrita fundamentalmente na norma constitucional. No Brasil, essa relação entre o STF e a Democracia ganha contornos mais fortes face ao sistema presidencialista que adota e que coloca o Poder Judiciário como fiscal dos direitos humanos e de proteção da soberania.

Diante destes debates e da crise da representatividade que se profunda na presente na conjuntura política - caracterizada pelo aumento da distância entre os interesses dos eleitores e os interesses dos candidatos e partidos eleitos, e pela concentração de poder - torna-se relevante o questionamento acerca da legitimidade democrática da tomada de decisões dos poderes estatais e, assim, igualmente do STF. A crise da representatividade contribui com o aumento de uma posição de protagonismo do STF sobre as decisões políticas, assim como, carrega uma crítica decorrente do próprio processo de observação da prática social acerca das democracias representativas. Portanto, a legitimidade democrática como paradigma das tomadas de decisões dos poderes do Estado Democrático de Direito se coloca não somente sobre quem deve deter a palavra final sobre a Constituição, mas também, sobre o procedimento democrático de tomada de decisão. Considerando esta perspectiva, o que se propõe no presente estudo, não é sobre a competência dada ao STF para o controle de constitucionalidade, mas analisar se suas decisões perpassam por uma procedimento democrático. Procedimento este que se colocará como parâmetro de aferição do aumento da legitimidade democrática do STF a partir da inserção das audiências públicas.

Em outras palavras, parte-se de uma análise consciente de que as decisões dos juízes tem implicações (sociais). Diante disso, opta-se pela análise das regras procedimentais do modelo de tomada de decisão, admitidos nas instituições, sob a perspectiva dos diferentes modos pelos 
quais se concebe a formação da vontade política nas teorias democráticas. Para tanto, convoca-se uma metodologia pós-positivista comprometida com uma intenção política cuja finalidade se funda na emancipação social dos indivíduos e na vivência solidárias entre eles. Considera-se que o sistema jurídico é lacunoso e contraditório, porém que tem o potencial para elaborar construções jurídicas que promovam e defendam a realização de interesses historicamente oprimidos, dada a sua capacidade de assegurar progressivamente espaços de poder a certos sectores e a certos interesses em desvantagem pela relação de forças existente na sociedade em seu cotidiano.

Com este objetivo, parte-se de uma noção da interpretação constitucional concretizadora e politizadora. $\mathrm{O}$ que não significa uma defesa a arbitrariedade do juiz constitucional político, mas a assunção de limites normativos no critério político presente na constituição e no diálogo participativo entre os cidadãos que compõe a vontade política coletiva presente. Em outras palavras, não cuida de uma redução política da metodologia jurídica, mas uma alternativa política ao direito. O repensar o Direito em uma sociedade reconhecidamente plural a qual demanda a comunhão de construções de diferentes identidades para a sua convivência solidária e justa para todos e todas. Uma justiça, por sua vez, compreendida na acepção da pluralidade de construção das personalidades pelo reconhecimento igualitário destas e na promoção de sua igual participação e inclusão na decisão coletiva.

Sendo assim, em um primeiro momento se contextualizará normativamente e empiricamente a inserção das audiências públicas e suas finalidades no procedimento de controle abstrato de constitucionalidade. Em seguida, se aprofundará no sentido democrático da expressão legitimidade democrática, com base numa dimensão discursivo-argumentativa, que se perspectiva e defende no uso das audiências públicas. Por fim, se verificará se legislativamente e, realisticamente, (através das audiências públicas já realizadas no STF), se estas de fato reforçam ou enfraquecem a legitimidade do STF com base nos pressupostos colocados a partir das teorias democráticas aferidas anteriormente. 


\section{AS AUdiêNCIAS PÚbliCAS: A SUA INSERÇÃO DAS AUdiÊNCIAS Públicas nos Processos de Controle de CONSTITUCIONALIDADE ABSTRATO}

A audiência pública ${ }^{1}$ é instrumento de que pode fazer uso o JuizRelator do Supremo Tribunal Federal (STF) em sede de controle de constitucionalidade concentrado para a requisição de informações adicionais, com a convocação de pessoas com experiência e autoridade na matéria, no caso de necessidade de esclarecimentos de matéria ou circunstância de fato ou de notória insuficiência de informações existentes nos autos (art. 21, XVII do Regimento Interno do STF). Estas audiências podem ocorrer após a manifestação dos legitimados ativos e passivos da ação de controle de constitucionalidade, quando o relator as requisitar, antes do julgamento. As audiências públicas nas ações judiciais de controle de constitucionalidade concentrado encontram-se

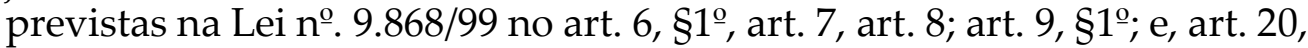
$\S 1^{\circ}$.

Com o intuito de regular tais audiências, em 18 de fevereiro de 2009, o STF editou uma emenda regimental (n.29) ao seu regimento interno. No que atine ao objeto desta pesquisa, esta emenda acrescentou dois incisos (XVII e XVIII) ao art. 13, conferindo o Presidente deste mesmo Tribunal a possibilidade de convocar audiências públicas e, estabelece o mesmo ao relator com a adição de dois incisos (XVII e XVIII) ao art. 21. A emenda acrescentou, ainda, ao art. 154, o inciso III, e um parágrafo único, possibilitando a marcação de audiências públicas e regulamentando o procedimento destas audiências.

De acordo com o art. 154, parágrafo único, do Regimento Interno do STF, as audiências públicas serão convocadas pelo Relator e pelo Presidente deste Tribunal através de um despacho convocatório no qual se fixará o prazo para indicação das pessoas que serão nelas ouvidas (art. 154, parágrafo único, inciso I do Regimento Interno do STF). Devendo-se garantir, em seu curso, a participação das diversas correntes de opiniões (art. 154, parágrafo único, inciso II do Regimento Interno do STF). Ao Ministro, que presidir a audiência, cumpre selecionar as pessoas a serem ouvidas, a divulgação da lista de habilitados, a ordem dos trabalhos e a fixação de tempo para a manifestação de cada um (art. 154, parágrafo

\footnotetext{
${ }^{1} \mathrm{O}$ presente trabalho se aterá à análise das audiências públicas realizadas no processo judicial em sede de controle de constitucionalidade concentrado. Não se ignora, entretanto, a existência de audiências públicas no âmbito da Administração Pública e no âmbito legislativo (art. 58, §2º, II da CF/88).
} 
único, inciso III do Regimento Interno do STF). O regimento interno impõe, também, que o depoente se limite ao tema ou questão em debate (art. 154, parágrafo único, inciso IV do Regimento Interno do STF) e que a audiência seja transmitida na TV Justiça e na Rádio Justiça (art. 154, parágrafo único, inciso $\mathrm{V}$ do Regimento Interno do STF). Por fim, os trabalhos produzidos nessas audiências devem ser registrados ou juntados aos autos do processo ou podem ser arquivados no âmbito da Presidência (art. 154, parágrafo único, inciso VI do Regimento Interno do STF). E, os casos de omissão devem ser resolvidos pelo Ministro que convocou a audiência (art. 154, parágrafo único, inciso VII do Regimento Interno do STF).

As audiências públicas nas ações em sede de controle de constitucionalidade abstrato no STF são inseridas em um contexto de crise de representativa que se configura sob a desconfiança com os poderes legislativo e executivo cada vez mais interessados em satisfazer determinados interesses pessoais em detrimento da vontade soberana a qual deveriam representar (art. $1^{\circ}$, I e parágrafo único c/c art. 14 da CRFB de 1988). Esta desconfiança decorre, ainda, da crescente insatisfação face às políticas neoliberais e à negligência para com a prestação social por parte da administração pública, os quais, somados ao discurso moral realizador-concretizador de valores da Constituição, intensificam o recurso aos tribunais, ampliando, assim, o seu protagonismo.

Com o objetivo de se anularem políticas que entram em conflito com os interesses da sociedade, sobretudo no que atine aos direitos sociais, a sociedade passa a procurar, cada vez mais, nas ações judiciais de controle de constitucionalidade, um meio eficaz para eliminá-las. O mesmo se pode afirmar em relação às omissões características na concretização do conteúdo constitucional, muitas vezes vezes não aprovadas porque correse o risco de serem fortemente contestadas publicamente. $\mathrm{O}$ recurso ao judiciário se revela, deste modo, o desenvolvimento de uma frustração para com os poderes legislativo e executivo no cumprimento da representação da vontade popular, e na ineficácia dos sistemas de controle e fiscalização e, deste modo, responsabilidade e accountability desta representação. Em suma, passa-se a desconfiar cada vez mais dos sistemas de democracia representativa através do voto majoritário.

Todavia, se por um lado a representação destes órgãos políticos é direta, no sentido de que se manifestam os interesses majoritários legitimados pelo voto no curso das eleições, o mesmo não pode ser afirmado no que atine ao STF nomeado por estes representantes (eleitos). A representação na instância judiciária é, então, indireta e fundada no exercício da garantia da lei constitucional, o que, por vezes, é visto de forma antidemocrática. Assim sendo, apesar do aumento da demandas 
por decisões jurídico-políticas pelo STF, face a insatisfação com os poderes políticos, este ainda é visto com muitas ressalvas de cunho democrático, pela sociedade que enxerga o processo eleitoral como meio de acessão democrática ao poder e de representação legítima da vontade popular.

Nesse contexto, apesar de prevista desde da publicação da Lei no․ 9868 em 1999, a primeira audiência pública somente veio a ser realizada pela primeira vez em 2007, pelo Ministro Ayres Britto, relator da ADI nº. 3510, na qual se impugnava dispositivos da Lei de Biossegurança (Lei 11.105/2005), caso comumente conhecido por: "pesquisas com célulastronco embrionárias" (BRASIL, 2008). No despacho de requisição da audiência o Min. Ayres Britto destaca a importância da realização da audiência pública, em suas palavras:

Daqui se deduz que a matéria veiculada nesta ação se torna de saliente importância, por suscitar numerosos questionamentos e múltiplos entendimentos a respeito da tutela do direito à vida. Tudo a justificar a realização de audiência pública, a teor do $\S 1^{\circ}$ do art. 9o da Lei 9.868/99. Audiência, que, além de subsidiar os Ministros deste Supremo Tribunal Federal, também possibilitará uma maior participação da sociedade civil no enfrentamento da controvérsia constitucional, o que certamente legitimará ainda mais a decisão a ser tomada pelo Plenário desta nossa colenda Corte. (grifo nosso)

No mesmo sentido, o Min. Gilmar Mendes, em seu voto na ADI no 3510/2007, afirmou que:

O Supremo Tribunal Federal demonstra, com este julgamento, que pode, sim, ser uma Casa do povo, tal qual o parlamento. Um lugar onde os diversos anseios sociais e o pluralismo político, ético e religioso encontram guarida nos debates procedimental e argumentativamente organizados em normas previamente estabelecidas. As audiências públicas, nas quais são ouvidos os expertos sobre a matéria em debate, a intervenção dos amici curiae, com suas contribuições jurídica e socialmente relevantes, assim como a intervenção do Ministério Público, como representante 
de toda a sociedade perante o Tribunal, e das advocacias pública e privada, na defesa de seus interesses, fazem desta Corte também um espaço democrático. Um espaço aberto à reflexão e à argumentação jurídica e moral, com ampla repercussão na coletividade e nas instituições democráticas.

Também o Ministro Luiz Fux, na recentemente julgada ADI no .4650 (BRASIL, 2015), sobre o financiamento de campanha eleitoral, defendeu a realização das audiências públicos no sentido de conferir maior legitimidade democrática às decisões do STF, na medida que esta possibilita com que o tribunal escute as vozes sociais. Por conseguinte, essas audiências gerariam uma maior confiança do povo para com as suas decisões. Além disso, no entendimento deste ministro, as audiências públicas são formas do STF prestar contas à sociedade de que as suas decisões sejam representativas da expectativa popular, sobretudo, naquelas ações que extrapolam critérios meramente jurídicos.

Portanto, seja da leitura dos dispositivos legais que preveem e regulamentam as audiências públicas, seja na sua aplicação prática por meio da manifestação dos juízes do STF, estas surgem envolta de uma necessidade claramente direcionada à legitimidade democrática de suas decisões e da impossibilidade do juiz deter o conhecimento técnico sobre todos os elementos que envolvem os objetos das ações constitucionais de sua competência, sobretudo neste contexto de aumento de seu protagonismo sobre decisões que, claramente, ultrapassam o estritamente jurídico. Em suma, as audiências públicas visam solucionar duas problemáticas decorrentes da interpretação constitucional: (i) a impossibilidade do juiz conhecer de todas as matérias no exercício interpretativo realizado no controle de constitucionalidade; (ii) e da legitimidade democrática de suas decisões.

Dessa maneira, as audiências públicas funcionariam não somente como mecanismo de consultoria pelo qual os juízes podem fazer uso para coletar informações pelas quais não tenham a expertise, mas também, como instrumento democratizador das decisões do tribunal o qual não possui os mecanismos de accountability impostos, por sua vez, aos poderes Executivo e Legislativo e os quais garantiriam com que houvesse respeito a vontade do povo. Em resumo, as audiências públicas nascem e desenvolvem-se sobre as problemáticas de cunho democrático do exercício interpretativo sobre o texto constitucional realizado pelo STF do qual se demanda cada vez mais uma atitude positiva e, assim, de cunho político, na defesa dos direitos previstos na Constituição. 


\section{A LEGITIMAÇÃo DEMOCRÁticA DAS DECISÕES EM SEDE DE CONTROLE DE CONSTITUCIONALIDADE CONCENTRADO: PARTICIPAÇÃO E DIÁLOGO}

A legitimidade democrática está intimamente relacionada com a inserção das audiências públicas no processo de controle de constitucionalidade abstrato. Nesse sentido, pode-se apontar três argumentos principais em relação às corte constitucionais, no que se refere à defesa de sua legitimidade democrática (BELLAMY, 2013, p. 332333): (i) sobre a deliberação do seu processo de tomada de decisão; (ii) sobre a participação popular da parcela da sociedade excluída no processo eleitoral; e, (iii) sobre o limite na representação da vontade popular inserida na norma constitucional. Cumpre, portanto, estabelecer os pressupostos pelo quais se fundam esta legitimidade democrática, ou seja, o que se compreende por democrático na legitimidade que se busca conferir à atuação do STF nesta função.

$\mathrm{O}$ primeiro argumento, acima destacado, afirma que as cortes constitucionais são uma instituição deliberativa, uma vez que adotam um processo de decisão deliberativo. $\mathrm{O}$ segundo argumento remete para a ampliação da participação a qual contempla uma intervenção democrática ao dar voz aos excluídos do processo eleitoral (BELLAMY, 2013, p. 332-333). Esta última característica é, também, dada em função de seu caráter deliberativo. O terceiro e último argumento (BELLAMY, 2013, p. 332-333), comumente utilizado para justificar democraticamente a competência do tribunal constitucional no controle de constitucionalidade, sustenta que os juízes constitucionais também são representantes, porém não como delegatários, mas enquanto curadores. Em outras palavras, as cortes constitucionais possuem legitimidade democrática, na medida em que também são representantes da vontade da sociedade que se encontra, todavia, inscrita na norma constitucional. De acordo com este pensamento, a justiça democrática não está separada de uma noção de "bem" definido pela sociedade na Constituição, a qual é aplicada pelos juízes constitucionais quando do julgamento das ações constitucionais (Nino, 1997 e BELLAMY, 2013, p. 345). Portanto, os juízes não podem achar que detêm o conhecimento ou a verdade sobre o bem coletivo, desqualificando a organização democrática, a estrutura social dos cidadãos e seus representantes (BELLAMY, 2013). Sendo assim, dois são os fatores indicativos da legitimidade democrática das decisões do STF: uma decisão que seja o produto de uma deliberação participativa e o limite de sua atuação na norma constitucional. Em outras palavras, considera-se as decisões do STF democráticas e, por isso, legítimo o exercício deste tribunal no controle de constitucionalidade porque suas 
decisões se baseiam em um processo decisório deliberativo, participativo e limitado ao conteúdo normativo extraído da Constituição.

Nesse sentido, cumpre destacar a importante obra de Peter Häberle (2002), Hermenêutica Constitucional: a sociedade aberta dos intérpretes da constituição. De acordo com essa obra, se antes a interpretação constitucional se restringia a um círculo limitado e fechado, composto pelos juízes constitucionais e por procedimentos formalizados, novos fatores sociopolíticos nos levam a verificar que a realidade constitucional é bem mais ampla do que este círculo. Logo, se antes a atividade interpretativa e o conteúdo constitucional se atinha a debates técnicosjurídicos, hoje, a Constituição e o seu significado, é debatido por diversos campos acadêmicos (como as ciências sociais, por exemplo) e não acadêmicos (como por certos grupos políticos, movimentos sociais), ou seja, de forma mais generalizada, pela população como um todo.

Peter Häberle argumenta que estes são atores de forças produtivas de interpretação que não devem ser excluídos do processo interpretativo tendo em vista a sociedade democrática. Dessa maneira, defende que a teoria da interpretação deve ser garantida sob a influência da teoria democrática, o que significa que todo aquele que vive no contexto regulado por uma norma, e que vive esse contexto, é, direta ou indiretamente, um intérprete da norma. Ou seja, uma vez que a interpretação tem impacto na própria realidade sociopolítica, ela tem efeitos sobre todos os que se encontram neste contexto e que, por esta mesma razão, irão opinar sobre seu conteúdo e desejarão dispor sobre ele. Uma vez que vivemos em sociedades democráticas formadas por instituições políticas, assim como, jurídicas, estas últimas, em sede de juízo de constitucionalidade, também devem abrir seus campos para a participação social (HÄBERLE, 2002). Então, em vista do pensamento de Peter Häberle (2002), a abertura interpretativa da constituição à participação social, inclusive por meio do aumento da previsão legal de legitimidade ativa para as ações de constitucionalidade, legitimam democraticamente as decisões do STF. O aspecto levantado pelo autor é, portanto, sobre o acesso ao STF e, consequentemente, do aumento da proximidade com a sociedade no debate constitucional.

Outro fundamento de legitimação democrática parte da perspectiva da capacidade das instituições em efetivar direitos fundamentais que compõem uma estrutura básica da sociedade, bem como do impacto que as decisões institucionais podem ter sobre o sistema institucional como um todo. Nesse sentido, parte da doutrina aponta para uma legitimidade democrática direcionada ao diálogo institucional, ou seja, entre os representantes eleitos dos poderes legislativo e executivo, e o STF. Entretanto, considera-se que a própria crise representativa da qual 
insurge a audiência pública, já demonstra que somente o diálogo institucional não é suficiente para gerar uma participação efetivamente democrática. Nesse sentido, defende-se que a abertura para os intérpretes constitucionais deve também abranger toda a sociedade, ou seja, reconhecer sua pluralidade.

A legitimidade democrática, envolve, então, a participação direta nos órgãos de tomada de decisão. Ou seja, ao se falar em aproximação da sociedade civil ou das vozes sociais, gerado pela inserção das audiências públicas nas ações de controle de constitucionalidade, se está a perseguir uma participação plural e direta de outros atores (ou intérpretes) no processo de tomada de decisão no STF. Por conseguinte, o problema da legitimidade passa da constituição do poder para decidir (poder político) para a estrutura das decisões, ou seja, como elas são formadas.

Segundo Jürgen Habermas (1995, p. 42-45) a legitimidade democrática dos tribunais constitucionais é desenvolvida a partir de uma visão deliberativa da democracia. $\mathrm{O}$ autor desenvolve, desse modo, uma teoria deliberativa sobre a formação de vontade no processo político - a qual também se inserem no âmbito dos tribunais - que se afasta do discurso liberal ou republicano, mas sem com elas se desconectar completamente. De acordo com o discurso liberal, o processo de formação da opinião e vontade política, na esfera pública, é determinada pela concorrência entres atores coletivos, cujas decisões são orientadas nos mesmos termos dos participantes de um mercado. Assim sendo, do ponto de vista liberal, a concorrência e a barganha determinam os interesses que serão protegidos e garantidos na tomada de decisão coletiva constituída pela soma de interesses exclusivamente individuais. Já, na concepção republicana, o espaço público não obedece às estruturas do processo de mercado, mas à estruturas de comunicação pública orientada para o entendimento. Segundo esta última concepção, a formação da vontade coletiva deve se dar pelo diálogo racional orientada não sobre preferências pessoais, porém sob valores comuns considerados justos pela sociedade, sobre o bem comum e o interesse público. Por sua vez, de um viés discursivo e deliberativo sobre a formação da vontade coletiva, Jürgen Habermas (1995, p. 45) expõe que:

O conceito de política deliberativa somente exige uma referência empírica quando levamos em conta a pluralidade de formas de comunicação as quais uma vontade comum pode se formar, não somente pela via de uma auto compreensão ética mas também mediante o equilíbrio de interesses e compromissos, mediante a 
escolha racional de meios com respeito a um fim, mediante justificações morais e exames de coerência jurídicos. (...) Portanto, tudo gira em torno das condições de comunicação e dos procedimentos que outorgam à formação institucionalizada da opinião e da vontade políticas sua força legitimadora.

Assim sendo, este autor não considera que os fins coletivos sejam exclusivamente um arranjo (ou uma cooperação) dos interesses privados conflitantes - conforme defendido pelos liberais - mas, também, não recai no idealismo excessivo dos republicanos que tornam o processo democrático dependente das virtudes dos cidadãos. Diferentemente destes, ele defende que haja um discurso dialógico racional com respeito pelos valores básicos consensuais de uma cultura. Logo, a legitimidade é aferida através da garantia de um procedimento deliberativo em conformidade aos princípios morais que pretendem ter validade geral (Ibidem). Além disso, sob uma visão habermasiana da democracia deliberativa, a legitimidade democrática das decisões do STF no controle de constitucionalidade também advém da própria possibilidade de diálogo institucional, tendo em vista, o princípio da separação dos poderes e os efeitos decorrente da representação política (HABERMAS, 1995, p. 143-148). Nesta ordem de ideias, a Corte Constitucional funciona como uma "instituição deliberativa" que fala e justifica por e através de razões públicas. O juiz, por sua vez, é concebido como "reason-giver", como interlocutor que não só fala mas, também, escuta e incorpora razões de outros atores (MENDES, 2011, p. 109), devendo despersonificar-se, ou seja, ter uma posição passiva de escutar e questionar (MENDES, 2011, p. 125-129).

Para esta teoria, portanto, o método de discussão e decisão coletiva é a única forma de aceder à verdade moral e, somente o consenso real formado a partir de um amplo debate com poucas exclusões, manipulações e desigualdade, é confiável para o acesso aos mandamentos morais (HABERMAS, 1995). Por fim, a teoria da democracia deliberativa afirma que a verdade moral se constitui pelo consenso enquanto resultado da prática real da discussão moral, levada a cabo em obediência a algumas restrições processuais de cunho moral compartilhados por todos os que definem as regras e que se colocarão pelo modo segundo o qual os argumentos serão exprimidos. Diante destes fatores, o agir comunicativo, à que se refere Habermas (2003), compreende uma atividade argumentativa que exige dos membros a assunção das perspectivas uns dos outros e de todos. Na deliberação não 
há escolha pura e simples do melhor argumento apresentado, como é apreendido em um sistema de votação para formação da vontade popular, mas pela formação de um entendimento comum do que é o melhor argumento alcançado conjuntamente através do diálogo. Não se confunde a deliberação com a negociação ou a mera retórica, ela observa certas exigências normativas que não estão presentes na negociação, as quais diferenciam a argumentação como agir comunicativo (Habermas, 2003), do agir estratégico do ato de negociar ou barganhar. A argumentação é, dessa maneira, direcionada para a ação coletiva tomada em comum - o que faz com que seja democrática - e não para a troca de promessas e ameaças que caracterizam a negociação.

Outro autor que em muito contribuiu com o debate acerca do conceito de democracia foi o cientista político Robert A. Dahl. Na sua obra intitulada Democracia, ele discorre sobre o conceito de democracia e estabelece 5 critérios fundamentais para um processo de governo cujos membros estejam igualmente habilitados para participar das decisões políticas, quais sejam: participação efetiva, igualdade de voto, informação esclarecida, controle de agenda e inclusão de todos os cidadãos que gozam de igualdade política (DAHL, 2000, p. 47-54). Da leitura deste autores, observa-se que a questão democrática na qual se insere a legitimidade do STF compreende, em síntese, uma visão procedimentalista da democracia sobre a qual se diferencia das demais teorias de democracia. Motivo pelo qual, foca-se, para os objetivos do presente estudo, sobre a tomada de decisão coletiva, e sobre seu processo de formação.

Especificadamente sobre o STF, o que se considera fulcral sobre a questão da legitimidade democrática é como a participação social se estabelece neste espaço decisório, tendo em vista a observância de um procedimento deliberativo na interpretação constitucional. Nesse intuito, não se deve descuidar dos próprios limites de competência decorrente da separação de poderes e, compreender que as análises da legitimidade democrática sobre as decisões em controle de constitucionalidade não podem ser confundidas com o processo político decisório em si. Sendo assim, a análise que se propõe sobre a verificação da amplitude da legitimidade democrática através da inserção das audiências públicas nas ações constitucionais no STF tem em vista justamente esta visão democrática-deliberativa, sobretudo, habermasiana, a qual se prende principalmente pela teoria do discurso que deve observar justamente os princípios do Estado de Direito e os direitos fundamentais, enquanto pressupostos comunicativos no procedimento institucionalizado. Em conclusão, a ampliação da legitimidade democrática através das audiências públicas no controle de constitucionalidade, a ser analisado 
no próximo item, se desenvolverá a partir da verificação das condições de comunicação e diálogo e no procedimento de formação da opinião política e da vontade político, através da verificação dos mecanismos de deliberação e participação na tomada de decisão.

\section{IV.O REFORÇO E/OU ENFRAQUECIMENTO À PARTICIPAÇÃO DEMOCRÁTICA NO CONTROLE DE CONSTITUCIONALIDADE CONCENTRADO}

Verifica-se, deste modo que a legitimidade democrática do controle de constitucionalidade realizado pelo STF fundamenta-se sob dois pilares: (i) o limite na norma constitucional; (ii) a decisão fundada em um modelo deliberativo-participativo. Sendo assim, questiona-se se a inserção das audiências públicas vem a de fato aumentar esta legitimidade democrática no controle judicial de constitucionalidade abstrato como finaliza. Por conseguinte, a análise que se segue sobre a legitimidade democrática se refere aos termos colocados no item anterior, quais sejam: a aplicação procedimental de uma tomada de decisão no STF deliberativa-participativa.

Para tanto, num primeiro momento, se abordará a questão da legitimação democrática sob a legislação que prevê e regulamenta as audiências públicas e, em seguida, se verificará mais algumas questões sob esta perspectiva no plano prático, ou seja, sob as audiências públicas já realizadas no STF. Uma vez que a norma legal não dispõe de forma detalhada sobre o procedimento das audiências deixando ao arbítrio do julgador a decisão de como proceder, considerou-se necessário a análise sob as audiências já realizadas, não se restringindo, assim, a legislação. Essa lacuna, além disso, cria outra dificuldade na análise, uma vez que cada audiência pública acaba por ter determinada peculiaridade em seu processamento, sobretudo, na análise do diálogo comunicativo, ou seja, na deliberação sob a qual se propõe este estudo. Optou-se, então, por fornecer ao leitor uma análise das audiência públicas realizadas como um todo sem adentrar na especificidade de como cada uma se sucedeu. Por fim, cumpre registrar que para a presente se baseou em vídeos disponibilizados no canal do STF no site Youtube e nas decisões das respectivas ações em que estas se desenvolveram.

\section{Análise sob a perspectiva democrática deliberativa-}




\section{participativa do texto legal}

Conforme visto no item anterior a audiência pública, na visão do STF, pretende contribuir para a participação social na formação do convencimento do julgador fortalecendo a democracia. Mas quem de fato pode participar?

A Lei 9.868/99 dispõe sobre "depoimentos de pessoas com experiência e autoridade na matéria", o que pode significar uma limitação às pessoas habilitáveis a participar da audiência. Isto porque restringe-se a participação de pessoas que o Ministro Relator considerou especialistastécnicos no assunto pertinente ao controle de constitucionalidade concentrado ajuizado. O que vai se de encontro a própria finalidade de aumentar a participação democrática, e contribui para que a jurisdição constitucional seja mais elitizada e afastada das lutas sociais (SANTOS, 2007, p. 66). Isto contribui para o fechamento, e não abertura dos interpretes constitucionais como colocado por Peter Häberle e, assim, ademais, o consequente afastamento do tribunal à realidade social. É o que se extrai da leitura da norma ao se referir expressamente à "expertise" que poderão compor as audiências públicas. Consequentemente, poderse-ia cogitar a exclusão de outros participantes que não buscam trazer informações técnicas mas, muitas vezes, a sua própria experiência vivida, igualmente válida e significativa sobretudo nas questões sociopolíticas. Portanto, esta limitação conflita com a própria aproximação à realidade social colocada por Peter Häberle e destacada no item anterior, além de fomentar a elitização do tribunal e, consequentemente, para seu fechamento à pluralidade de vidas existentes socialmente (SANTOS, 2007, p. 66). Pelo exposto, esta norma se contrapõe, em última instância, portanto, para a ideia de aumento da legitimidade democrática defendida no item anterior.

Dada esta limitação participativa a priori e, ainda, o fato de o Relator que convocou a audiência possuir discricionariedade na escolha de quem poderá participar nesta, entende-se que seja necessário uma reforma legislativa no sentido de dispor sobre parâmetros mínimos que vinculem esta escolha. Tais parâmetros devem perquirir uma formação verissímil com a pluralidade existente na própria sociedade sendo a mais heterogênea possível. Não se exclui, todavia, a necessidade de vinculação dos participantes com a temática em debate, o que, por outro lado, não significa a escolha exclusiva de especialistas como imposto pela literalidade desta lei.

Em relação ao tempo estabelecido, a legislação em análise não tece maiores comentários, optando por deixar ao arbítrio do julgado a determinação do tempo de manifestação de cada participante 
selecionado para a audiência pública, sem fazer, ao menos, qualquer referência à observância do princípio da igualdade. Contudo, levando em consideração uma constituição heterogênea adequada à pertinência temática no controle de constitucionalidade sub judice, deveria se estipular tempo de manifestação equânime entre os argumentos a serem trazidos pelos selecionados para compor a audiência. Assim sendo, aqueles que se colocam pela constitucionalidade deveriam dispor de mesmo tempo de exposição daqueles que se colocam pela inconstitucionalidade. Sendo que, dentro destes macros grupos (da inconstitucionalidade e da constitucionalidade), cada um dos membros deste grupos também deveriam dispor do mesmo tempo para manifestação. Por fim, considera-se importante observar que o tempo deve ser suficientemente hábil e razoável para uma exposição face a complexidade do tema. Além disso, já que não ha qualquer menção a observância de uma parâmetro isonômico, há um real risco de que tal arbítrio possa vir a construir uma audiência não democrática, onde um determinado argumento ou grupo tenha mais tempo para expor suas ideias do que outro.

Por fim, cumpre registrar uma das considerações acerca da legislação acima mencionada que se considera mais problemática do ponto de vista democrático. Referir-se-á livre disposição de que goza o julgador para arquivar ou juntar aos autos do processo os trabalhos da audiência pública. Segundo a legislação, se o julgador considerar que seja o caso, ele pode descartar todo o trabalho realizado em audiência, desprezando a participação popular no âmbito dessas audiências, sem a necessidade de fundamentar esta decisão. $\mathrm{O}$ juiz pode optar por simplesmente ignorar toda a manifestação realizada nessas audiências e concentrar o julgamento na sua própria racionalidade, não tornando público aos demais ministros o conteúdo destas audiências. Por outro lado, tal precariedade estaria parcialmente compensada pela obrigação legal de divulgação da audiências junto a Rádio e TV Justiça (art. 154, parágrafo único, inciso V do Regimento Interno do STF). Apesar disto, a escolha arbitrária sobre realização ou não das próprias audiências já contribui com o seu descrédito e pode acarretar um desestimulo a nelas se participar.

\section{Análise sob a perspectiva democrática deliberativa- participativa das audiências públicas realizadas}

As audiências realizadas pelo STF, em sua maioria, são formadas em grande parte por técnicos, ou seja, especialistas no assunto principal do controle de constitucionalidade concentrado. Isto demonstra uma 
tendência exposta pelo próprio STF - seja nos despachos para convocar a audiência, seja em entrevistas e notícias fornecidas no site do tribunal de fazer uso destas com o intuito de ampliar as informações colhidas sobre o objeto do processo. Isto é muito importante uma vez que, mostra uma consciência por parte dos ministros daquela corte sobre as suas próprias limitações. Cabe ao juiz, de fato, no exercício de suas atribuições, conhecer do direito, mas não de todos os problemas existente no mundo a fundo.

Por outro lado, as audiências públicas não são capazes de revelar de forma definitiva a legitimação democrática ou a democratização deste tribunal. Nesse sentido, observou-se que quem é chamado ou selecionado a participar e seu modus operandi, apresentam características que se afastam da ideia de democracia que tenha por pressuposto a participação dos cidadãos nas decisões que lhes afetem e que seja formada de forma dialógica. Na medida em que a maioria dos participantes verificados naquelas audiências são especialistas, e face a sua estrutura expositiva e não dialógica-dialética, verifica-se que este instrumento serve muito mais de inter disciplinarização das decisões do tribunal (informando os juízes de assuntos que fogem da seara jurídica), do que como forma de deliberação política. Em suma, a aproximação do Tribunal se dá com uma parcela limitada da sociedade, especialmente à comunidade científica e de especialistas e não alcança uma deliberação política, servindo, assim, em realidade, de mitigação de um déficit de conhecimento especializado dos ministros cujo conhecimento técnico de todas as áreas do saber é impossível.

Cumpre destacar que na maioria das audiências os Ministros que vão compor a turma para julgamento da ação em controle de constitucionalidade comparecem às audiências, assim como as partes (legitimados ativo e passivo). Por outro lado, a análise acerca das audiências realizadas não chega a qualquer conclusão definitiva de o quanto (não)heterogênea foram tais audiências. Ou seja, sobre as razões que fariam com que tais audiências pudessem satisfazer uma formação heterogênea conforme se propôs no item anterior. Apesar disso, a clara quantidade de argumentos técnicos levam a conclusão de que ha um déficit representativo e, que o equilíbrio acerca dos vários argumentos contra ou a favor de uma (in)constitucionalidade não podem ser alcançados. Isto pode ocorrer por conta de quem se propôs a participar e que tenha enviado e-mail em tempo hábil para requisitar a participação, assim como, pela falta de pedidos de participação, em razão de outros fatores, como os custos para ir até Brasília, por exemplo.

É possível observar, ainda, que em todas as audiências destacadas do quadro acima, os ministro, ao determinarem o tempo de exposição, 
costumam dispor entre 10-20 minutos para cada participante. É de ressalvar que isto pode gerar alguns problemas. Isto, porque, se houver o maior número de participante que defendem um determinado argumento, o tempo disponível para este será maior que os outros, perpetuando-se, assim, uma desigualdade na participação. Ressalva-se, contudo, que os participantes enviam um relatório do que será exposto anteriormente, o que pode auxiliar os ministros à disporem melhor acerca de um tempo hábil.

Além disso, a recepção prévia, pelo Juiz-Relator, sobre o posicionamento dos possíveis participantes poderia promover a oportunidade dos diferentes posicionamentos apresentados de se reunirem em diálogo sobre a melhor distribuição de tempo, de modo a tornar a participação parte da própria estrutura de organização das audiências públicas, ou seja, de sua formação e, evitando, deste modo, inclusive, a repetição de argumentos. Isto permite, ainda, que as partes possam se preparar anteriormente às audiências para que suas exposições não ultrapassem o tempo determinado, já que este é disposto no despacho que chama para a realização da audiência pública. Por outro lado, não foi possível fazer qualquer conclusão genérica acerca da suficiência do tempo que os ministros costumam dispor, uma vez que isto pode variar em razão da complexidade do tema, por exemplo. Apesar disto, observase que durante as audiências as partes costumam ultrapassar o tempo, o que é corretamente compensado na exposição dos demais participantes.

Outro fato interessante acerca dos dados das audiências públicas é que nos despachos da chamada para a audiência sempre há menção acerca do tema, em restrição ao conteúdo a ser exposto nesta. Por exemplo, em algumas audiências foram vedadas a exposição de relatos pessoais e/ou qualquer manifestação sobre interpretação jurídica. Essas restrições de conteúdo, podem gerar uma limitação do enfoque democrático que se almeja, uma vez que excluem de antemão a manifestação de como o direito afeta a realidade social (no primeiro caso), ou novas interpretações jurídicas não pensadas pelos juízes ou partes do processo (no segundo caso).

Outro ponto a ser destacado destes despachos é a referência aos participantes (como optamos por denominar no quadro acima) enquanto expositores ou palestrantes. $\mathrm{O}$ que pode parecer, em um primeiro momento, uma mera questão terminológica, entretanto, acaba por refletir, em realidade, a forma pela qual se desenvolve as audiências: um local de reunião de diferentes manifestações orais. As audiências não tinham o caráter dialógico nos moldes de um sistema democrático participativo- deliberativo. 
Por fim, todas as audiências públicas realizadas obedeceram a determinação do Regimento Interno do STF, no 29 (art. 154, parágrafo único), segundo a qual as audiências devem ser sempre públicas. Sobre este ponto, nota-se quão poucos são os ministros - que não o relator da ação em controle de constitucionalidade - que participaram das audiências. Apesar disto, em todos os casos analisados, as transcrições das audiências foram juntadas aos autos dos respectivos processos. Logo, mesmo havendo poucos ministros nelas presentes, à todos tiveram acesso ao conteúdo delas. Por outro lado, não há como se afirmar até que ponto essas transcrições contribuem para a formação dos votos dos juízes nas decisão, seja porque nem sempre os argumentos apresentados nelas são expressamente mencionados nos votos, seja por conta de alguns casos ainda não terem sido julgados.

Tendo tudo isto em vista, considera-se que as audiências públicas possuem um potencial deliberativo que de fato às coloca no caminho da legitimidade democrática. No entanto, os moldes pelas quais elas tem se realizado e positivadas em lei, não são suficientes enquanto instrumento definitivo de qualificação da democraticidade do tribunal. De qualquer modo, não se pode olvidar de suas potencialidades, em relação a visibilidade que grupos historicamente oprimidos ${ }^{2}$. Porém, seus limites, sobretudo no sentido da formação de um espaço de diálogo, encontram restrições não somente de conteúdo, mas que recaem sobre aspectos mais profundos da teoria do discurso que dizem respeito à própria igualdade de valores identitários existentes socialmente. Sobre este ponto, as audiências públicas poderiam, ademais, possibilitar, uma maior participação das partes processuais (legitimados ativos e passivo e o amicus curiae) e dos juízes neste diálogo, assim como, ter papel mais significativo dentro das ações de controle de constitucionalidade de modo a, de fato, comporem as decisão do STF.

Por fim, cumpre mencionar que o sentido dialógico almejado para as audiências públicas, deveria perspectivar a sua constituição como espaço público heterogêneo. Um local onde o ser humano pode não somente

2 Esta expressão tem por base o conceito delineado por Iris Marion Young (1990). Segundo a autora estes grupos seriam homossexuais, mulheres e negros. A opressão é definida por Iris Marion Young como um conjunto de condições e conceitos, sendo eles: exploração, marginalização, impotência, imperialismo cultural, e violência (1990, pp. 39-65). Este conceito de opressão não é compreendido, portanto, como o resultado de políticas de poucas pessoas, mas é inserido no cotidiano da vida, na prática dos bem-intencionados da sociedade liberal. Além disso, afirma a autora, que essas condições e conceito que definem ou identificam os grupos oprimidos são combinadas de forma e em dimensões diferentes à depender da particularidade de cada grupo. 
aprender sobre os outros, mas igualmente sobre a coletividade e, ainda, sobre a sua posição pessoal nesta coletividade, como sujeito inserido nela, como membro e como pertencente a esta (PITKIN, 1981, p. 345). Uma vez que se forma uma decisão sobre o que fazer, socialmente, inevitavelmente, decide-se, simultaneamente, o que cada um terá e como nós, enquanto comunidade, seremos (PITKIN, 1981, p. 346). O espaço público, sob esse paradigma, é compreendido não como local em que o cidadão apresenta a imagem do seu ser sob uma audiência, mas como autor na definição coletiva do "eu". Determina-se, dessa maneira, conjuntamente não o que se é, mas o que se deve ser (PITKIN, 1981) em respeito às diferenças identitárias, cujo desenvolvimento também compreende a interação com o meio ambiente em que se inserem, e com o seu reconhecimento. A verdadeira participação na ação política, sob esta perspectiva do espaço público, é capaz de conscientizar sobre a conexão remota e indireta uns com os outros, resultado da solidariedade que, não somente, pressuposto, mas também seu fim. A partir desta noção, está-se obrigado a reconhecer o poder dos outros e a apelar aos parâmetros alheios, mesmo que se procure fazer com que reconheçam o nosso poder e os nossos parâmetros. Somos forçados a encontrar e criar uma linguagem comum pelos propósitos e aspirações, não meramente para vestir nossa roupagem privada na distinção pública, mas para conscientizarmo-nos do seu significado público. Somos forçados a transformar o "eu quero" num "eu tenho direito a".

Cuida-se, ainda, de pensar sobre os próprios parâmetros, sobre nossa posição na existência destes parâmetros, sobre justiça e sobre nossa comunidade, e até mesmo sobre nossos oponentes e inimigos nesta comunidade (PITKIN, 1981, p. 347). Desse modo, como nosso pertencimento à coletividade nos ajuda a nos definirmos, tal como, o prazer em tornar-se ativo na relação com esta forma de vida conjunta, ou seja, tornar-se consciente de que os interesses próprios são igualmente produto do reconhecimento da demanda dos outros. O direito não deve ser sobre o interesse próprio, nem sobre auto sacrifício, e sim sobre a autorrealização de uma pessoa não completa - auto realização nos dois sentidos da palavra: tornar real o que é potencial no pessoal e realizar o que alguém realmente é (PITKIN, 1981, p. 348).

Somente na interação com várias e diferentes pessoas, somente na relação com o "nós", se pode alcançar este conhecimento. Em outras palavras, eu não posso descobrir completamente quem eu sou, aprender o julgamento público, exclusivamente pelas relação privadas (PITKIN, 1981, p. 349). Por este motivo, o diálogo nos processos judiciais deve sempre buscar uma maior proximidade com a pluralidade de identidades 
existentes socialmente de modo à não excluir nenhum tema aprioristicamente a não ser por escolha das próprias partes envolvidas.

Em resumo, apesar do importante potencial deliberativo das audiências públicas, estas acabam por se restringirem a uma visibilidade meramente de presença, mas não são capazes de tornarem presente e efetiva a participação dialógica, mais heterogênea e, inclusiva. A presença de múltiplas perspectivas culturais e sociais no debate político possui a vantagem de ampliar a qualidade epistêmica destes, mas não se pode deixar de considerar que, sem postular qualquer derivação mecânica ou determinista, ela não é capaz de conter a tendência para a reprodução das hierarquias e, assim de dominação pelo discurso. Não significa que a audiência pública, seja irrelevantes e desprovidos de importância, mas é preciso considerar em suas relações comunicativas ou dialógicas, as relações de força que nelas se efetivam sob uma forma transfigurada (MIGUEL, 2010) e como se revelam na aplicação de um suposta racionalidade imparcial. Por estas razões que se defende que as audiências públicas deveriam compor de forma mais significativa a decisão em sede de controle de constitucionalidade abstrato, desde que, ademais, respeitados estes procedimentos dialógico-comunicativos, ou seja, um agir comunicativo, como expressado por Habermas.

\section{CONCLUSÃo}

Os debates que envolvem a legitimidade democrática e decorrem o surgimento das audiências públicas, fazem parte de uma problemática maior que envolve a representação da vontade popular nos 3 poderes estatais (poder legislativo, executivo e judiciário). Nesse sentido, o Poder Judiciário e, especialmente, o STF, não fogem às críticas de viés democrático em relação a representação da vontade popular.

Por sua vez, a questão democrática de fundo que envolve a temática passa pela afirmação de que democracia é o governo do povo, para o povo e pelo povo. Sendo assim, a participação ocupa lugar decisivo neste conceito de democracia e que refere ao povo participante, no poder. Não há, de fato, democracia sem participação. E a participação aponta para as forças sociais que vitalizam a democracia e lhe assinam o grau de eficácia e legitimidade no quadro social das relações de poder, bem como a extensão e abrangência desse fenômeno político numa sociedade repartida em classes ou em distintos esferas e categorias de interesses (BONAVIDES, 2009, p. 826). A democracia pressupõe, assim, o povo como sujeito de poder (BONAVIDES, 2009, p. 828).

O STF também está sujeito aos princípios da soberania popular, do respeito integral aos direitos fundamentais da pessoa humana e a 
representação da vontade popular a qual será por sua vez mais democrática, quanto maior for a participação direta dos representados, para opinar, deliberar, fiscalizar (BONAVIDES, 2009, p. 726). Sendo, assim, a exigência de participação popular está no que existe de mais moderno no sentido democrático, como combinação entre democracia representativa e as várias expressões de democracia direta. A democracia atual questiona a representatividade e demanda maior participação e deliberação como correção da democracia representativa através da participação direta do principal interessado no desenvolvimento da sociedade, o povo. Neste sentido, parte-se de uma noção democrática que compreende um processo de participação dos governados na formação da vontade governativa (BONAVIDES, 2009, p. 827) e que aponta invariavelmente para a maior participação e emancipação social. Portanto, a legitimidade democrática do STF deve atravessar este discurso democrático em suas decisões através da desobstrução dos caminhos de participação (BONAVIDES, 2009, p. 834), ou seja, com o aumento da participação popular.

Apesar disto, o Supremo Tribunal Federal representar um elemento útil na articulação das práticas sociais emancipatórias nesses últimos anos, ao mesmo tempo movimenta-se em uma zona fronteiriça entre a debilidade institucional e as práticas sociais emancipatórias, de modo a transitar entre o conservadorismo e o espaço de emancipação das práticas sociais. Igualmente, as audiências públicas, apesar dos limitantes apontados durante o estudo podem tornar-se um espaço público heterogêneo de participação e instrumento de emancipação das práticas sociais dentro dos limites institucionais (estruturais) do STF. Porém, deve-se estar consciente dos limites institucionalmente instransponíveis das audiências públicas, sobretudo, acerca do espaço geográfico e da demanda de tempo da decisão. Ou seja, ir até Brasília, o custo de elaboração das propostas de manifestação, o tempo insuficiente, a restrição temática, o domínio/conhecimento acerca da linguagem e do método de argumentação mais eficiente, à exemplo. Tais elementos, por si só, já representam diferenças entre interesses em jogo os quais somente são aprofundados dentro da institucionalização deliberativa nas audiências públicas. O próprio discurso institucionalizado é um produto completo de desigualdade, na medida em que pressupõe um conhecimento técnico (regras do discurso) (BOURDIEU, 2007, p. 130-131) que não parte de uma relação igualitária. Por isso que ao final se conclui que as audiências públicas não são capazes de aumentar a participação social e representar um campo deliberativo eficaz como se pretende, mas somente de mascarar a reprodução de poder e de injustiça. 
No entanto, isto não impede com que as mudanças aqui propostas em relação as audiências e seu significado no processo decisório ampliem ainda mais à participação para além dos legitimados para a ação direta de inconstitucionalidade e para a ação declaratória de constitucionalidade. Assim sendo, para a construção de espaços de real deliberação democráticas deve-se buscar uma participação realmente inclusiva, capaz de reunir os diferentes interesses presentes na sociedade que poderia se realizar através delas.

Conclui-se que o problema das audiências públicas não está nas finalidades, mas na sua estrutura e na forma pela qual se desenvolve nessas estruturas sociais desiguais as quais não são capazes de solucionar o formato como se realizam na atualidade. $\mathrm{Na}$ atualidade, na forma pela qual se realizam, não são capazes de criar espaços deliberativos efetivamente democráticos de inclusão dos diversos interesses sociais, os quais demandariam uma participação no planejamento e, no processo decisório do tribunal no curso do controle de constitucionalidade concentrado, por meio de uma sociedade já emancipada, ou seja, igual e livre.

\section{REFERÊNCIAS}

BELLAMY, Richard. The democratic qualities of courts: a critical analysis of three arguments. Representation, v. 49, n. 3, p. 333-346, 2013.

BONAVIDES, Paulo. A democracia participativa e os bloqueios da classe dominante. Direitos humanos, democracia e República: homenagem a Fábio Konder Comparato. São Paulo: Quartier Latin, p. 825-840, 2009.

BOURDIEU, Pierre. A distinção crítica social do julgamento. Edusp, 2007.

BRASIL. Supremo Tribunal Federal. Acórdão na Ação Direta de Inconstitucionalidade no 3150/DF. Distrito Federal, 29 de maio de 2008. Relator: Ministro Ayres Britto. Disponível em:

$<$ http://www.stf.jus.br/portal/jurisprudencia/listarJurisprudencia.asp?s1 $=\% 28$ ADI $\% 24$. SCLA.+E+3510.NUME. $\% 29+O U+\% 28$ ADI.ACMS.+ADJ2+3 510.ACMS.\%29\&base=baseAcordaos\&url=http://tinyurl.com/av7pz4c>. Acesso em: 05 ago. 2018.

. Acórdão na Ação Direta de Inconstitucionalidade nº 4650/DF. Distrito Federal,17 de setembro de 2015. Relator: Ministro Luiz Fux. 
Disponível em:

$<$ http://stf.jus.br/portal/jurisprudencia/listarJurisprudencia.asp?s1=\%28A CAO+DIRETA+DE+INCONSTITUCIONALIDADE+4\%2E650+DISTRIT O+FEDERAL\%29\&base=baseAcordaos\&url=http://tinyurl.com/y9fkxol>. Acesso em: 05 ago. 2018.

DAHL, Robert A. 2000. Democracia. Lisboa: Ed. Temas\&Debates.

HÄBERLE, Peter. 2002. Hermenêutica Constitucional: a sociedade aberta dos intérpretes da Constituição para a interpretação pluralista e "procedimental" da constituição. Traduzido por Gilmar MENDES. Porto Alegre: Sergio Antonio Editor.

HABERMAS, Jürgen. Três modelos normativos de democracia. Lua nova, v. 36, p. 39-53, 1995.

Direito e democracia: entre facticidade e validade. Tradução de Flávio Beno Siebeneichler. Rio de Janeiro: Tempo Brasileiro, 2003.

MENDES, Conrado Hübner. Deliberative performance of constitutional courts. 2011. Tese de Doutorado. University of Edinburgh. Disponível em:

$<$ https://www.era.lib.ed.ac.uk/handle/1842/5974>.

MIGUEL, Luis Felipe. Perspectivas sociais e dominação simbólica: a presença política das mulheres entre Iris Marion Young e Pierre Bourdieu. Revista de Sociologia e Política, v. 18, n. 36, 2010.

NINO, Carlos Santiago. La constitución de la democracia deliberativa, trad. Roberto P. Saba, Gedisa, Barcelona, 1997.

PITKIN, Hanna Fenichel. Justice: On relating private and public. Political theory, v. 9, n. 3, p. 327-352, 1981.

SANTOS, Boaventura de Sousa. 2007. Para uma revolução democrática da justiça. 3ํㅡㄹ ed. São Paulo: Editora Cortez.

YOUNG, Iris Marion. Justice and the Politics of Difference. Princeton University Press, 1990. 
A INSERÇÃO DAS AUDIÊNCIAS PÚBLICAS: REFORÇO OU ENFRAQUECIMENTO DA LEGITIMIDADE DEMOCRÁTICA DAS DECISÕES DO SUPREMO TRIBUNAL FEDERAL?

THE INSERTION OF THE PUBLIC HEARINGS: STRENGTHENING OR ENHANCING THE DEMOCRATIC LEGITIMACY OF THE DECISIONS OF THE BRAZILIAN SUPREME FEDERAL COURT?

Submetido em: 2017-11-09 Aceito em: 2018-07-01 